\title{
Yugoslavia Vanishes:
}

\section{The British Turn to the}

\section{Serbian Question}

\section{J O H N R L A P E}

Tim Judah, The Serbs, History, Myths and the Destruction of Yugoslavia, 3rd ed. (New

Haven and London: Yale University Press, 2009), 474 pp., \$I9.00 (pb), ISBN 9780300158267 .

Vesna Drapac, Constructing Yugoslavia, A Transnational History (Houndsmills, UK and New York: Palgrave Macmillan, 20Io), 335 pp., \$32.95 (pb), ISBN 978033392553. Dejan Djokić, Elusive Compromise, A History of Interwar Yugoslavia (New York: Columbia University Press, 2007), 3II pp., \$32.50 (pb), ISBN 9780231700207. Marko Attila Hoare, The History of Bosnia, From the Middle Ages to the Present Day (London: SAQI, 2007), 5Io pp., £35 (hb), ISBN $978086356953 \mathrm{I}$.

A generation has now passed since the former Yugoslavia vanished in the early I990s. With it went the long concentration of Anglo-American scholarship on the multiethnic promise of the Yugoslav idea and the reality of a communist regime struggling to make it work as a federation. But unlike the lady who vanished on a Balkan train trip in Alfred Hitchcock's famous film only to turn up again, respectful scholarly interest has not reappeared. The violence of Yugoslavia's dissolution in the I99os led many of the former legion of Yugoslav specialists to simply abandon the subject, while others were caught up in the search for the earliest warning signs of failure. Concentrated in the social sciences and on current conditions, the large American cohort soon lost almost all of its economists, further depleted by the concurrent collapse of the Soviet Union and the special field of comparative economic systems. Political scientists retreated as well. The fatal combination of single-party republic regimes and a flawed socialist theology with enduring ethnic divisions had proved to be more than a match for the federal framework, independent foreign policy and 
workers' self-management that had previously drawn so much constructive attention and criticism. ${ }^{1}$

Looking back to find earlier, pre-communist forewarnings of failure favoured history over political science in any case. And from the post-I945 period onwards, British scholarship has paid more attention than the American cohort to venturing back before I945 to connect the overlapping history of the South Slavs, the initial Yugoslav idea, and the inter-war state with the communist era. The British ranks already favoured historical narrative over the thematic approaches of the social sciences. As Charles King has noted, the special British interest in national ideas has a broader, multi-disciplinary base. He dates it back to a nineteenth century interest in the unification of Greece, Italy and Germany, then expanded by the twentieth-century attraction to the history of ideas (Isaiah Berlin, Alfred Cobban and Elie Kedourie) and to the dynamics of nationalism (Eric Hobsbawm, Benedict Anderson, Ernest Gellner and Anthony Smith). ${ }^{2}$

This framework has suited both Yugoslav unification and now the competition between ethno-national ideas that moved from the republics during the I980s into the successor states. A mixture of British historians, journalists and diplomats has worked since the I990s to connect that decade's destructive politics with the various national ideas and the pre-modern history of what became the successor states. Recent volumes on Montenegro, Croatia and Serbia have joined Noel Malcolm's works on Bosnia and Kosovo in concentrating on these earlier centuries. ${ }^{3}$

The current generation has turned its back on the past body of British scholarship represented by the authors of the two successive Cambridge University Press histories of Yugoslavia, Stephen Clissold in I966 and Fred Singleton in I984. Not incidentally, Clissold came from the cadre of British officers who served with the military missions in Yugoslavia during the Second World War; Singleton represents the strain of British political sympathy for an independent socialist experiment. Both volumes spent little time or paid little respect to the inter-war state but expressed no doubts about the Yugoslav idea and the premise of multi-ethnic accommodation underlying it. They framed their appreciation of post-I945 prospects with more attention to the pre-I9I4 period. ${ }^{4}$

1 For a perceptive study emphasising the political failings of the constitutional framework and socialist self-management, ethnic divisions aside, see Dejan Jović, Yugoslavia, A State That Withered Away (West Lafayette, IN: Purdue University Press, 2009).

2 Charles King, Extreme Politics, Nationalism, Violence and the End of Eastern Europe (London: Oxford University Press, 20IO), I9-23.

3 Elizabeth Roberts, Realm of the Black Mountain, A History of Montenegro (London: Hurst, 2007); Branka Magaš, Croatia Through History, The Making of a European State (London: SAQI, 2007); Sima M. Ćirković, The Serbs (London: Blackwell, 2004); Noel Malcolm, A Short History of Bosnia (London: Macmillan, I994); Noel Malcolm, Kosovo, A Short History (New York: New York University Press, I998).

4 Stephen Clissold, ed., A Short History of Yugoslavia (Cambridge: Cambridge University Press, I966), 7, concluded his own Introduction by stating that ' . . though the cost may be high, the momentum of the new state is undeniable ... Post-war Yugoslavia is of a tougher texture than the inter-war state'. Fred Singleton, A Short History of the Yugoslav Peoples (Cambridge: Cambridge University Press, I984), $\mathrm{x}$, confesses 'to a deep and abiding affection for Yugoslavia and an admiration for the people and their 
Post-1989 publications have looked instead to disparate ethnic groups whose differences and difficult interrelations explain why the former Yugoslavia and the multi-ethnic idea behind it failed to work. The four volumes reviewed here represent both how this is being done and who is doing it. Their common focus of their inquiries seems to be the Serbian question, i.e. what role Serbs, in Croatia or Bosnia as well as Serbia, and Serbian state interests played on the historical stage set for Yugoslavia's demise. Tim Judah is one of several British journalists whose first-hand coverage of the I990s warfare generated a book based on the state's violent breakup. His base in Belgrade also allowed him to concentrate on the initiatives and excesses of the Milošević regime that made Serbia, as he says in his Introduction, 'the villain of the piece'. But rather than add to the dozen biographies of Slobodan Milošević that have since appeared or omit the misdeeds of other wartime leaders, Judah tells a more complex story. He juxtaposes the elements of Serbian history and mythology accumulated by the early twentieth century with the way in which Miloševićs regime drew on them for popular support. In this account, he pays even less attention to the formation and experience of inter-war Yugoslavia than Clissold and Singleton.

The other three new volumes do pay attention to this 'first Yugoslavia' and, despite their concentration on the Serbian question, repair some of the past neglect. The authors share common origins from or in the former Yugoslavia, then followed by British or American doctoral training. Vesna Drapac took her doctoral degree and has published in French history, while Dejan Djokic and Marko Attila Hoare have expanded their dissertations for the volumes at hand. Drapac concentrates on the origins of the inter-war state and condemns it as unification in the name of a multi-ethnic Yugoslavia but forced on Croatia by a British preference for Serbian predominance. She calls for a return rather than a turn to the question of Serbian hegemony. For Djokić, it is the Serb-Croat question. He argues against a priori assumption of Serbian and Croatian national ideas as incompatible and emphasises instead their internally divided political leaders and their repeated if flawed efforts to find a working arrangement within the borders of the inter-war state. Hoare adds Bosnia-Herzegovina to the growing list of former republics whose histories are now treated as separate subjects. Unlike several recent works cited above, he usefully devotes the bulk of his account to the twentieth century and focuses on the inter-war period and the Second World War; he tracks Bosnia's troubled engagement with the Serbian question, comparable with Drapac's dire assessment for Croatia but contrasting with Djokić's account of the inter-war search for at least a Serb-Croat compromise.

The first half of Judah's book focuses on the emergence of the Serbian national idea in the century or more preceding the First World War. He highlights the assimilationist assumptions that left little room for the Yugoslav idea of related but separate South Slav peoples co-existing within some sort of single state. The second half provides a close and convincing account of the central Serbian role in the warfare

achievements'. Appreciative chapter titles such as 'The Transition to Socialism' cover the first 25 years of the Tito regime. 
that made the second Yugoslavia's dissolution in the I99os an invitation to look back in time for Serbian footprints. Written for the general reader, unlike the other three volumes, Judah's short chapters and frequent subtitles complement a vivid and concise narrative. His prose creates a momentum that pulls the reader along, helping us to understand why a third edition has now appeared. Two new chapters review the post-Milošević decade in a Serbia now disconnected from Montenegro and Kosovo as well as the rest of the former Yugoslavia.

Yet Judah does not draw the straight line that others have from Serbian history and its mythology of heroism and victimisation to the abuses of non-Serbs by the Milošević regime. He stresses its cynicism and corruption rather than its nationalistic convictions, while also pointing to the absence of innocent virtue on the other sides. The collective memory of this mythology was, however, there to be used, and the Milošević regime used it to repeated advantage. It is in this sense that Judah stands back from the contemporary judgment of the Serbs as 'the villains of the piece'.

Throughout, his use of the available secondary sources, primarily in English, is extensive and balanced, avoiding the temptation to draw only on advocacy for one side. His promise to detail the origins of available Serbian mythology is better kept than its connection to the Serbian state's political history preceding the founding of the Yugoslav kingdom in I9I8-2I. We are better served for his treatment of the folk epic and literary foundations of Serbian historical memory, typically tied to their specific use by the Milošević regime. Judah's literary figures come from the nineteenth century: Vuk Karadžić, the primary translator of Serbian folk epics lamenting the 1389 loss of the Kosovo battle and the medieval Serbian state, and the Montenegrin poet-bishop, Petar Petrović Njegoš, whose poem The Mountain Wreath advocates no mercy to Muslims in creating a wider Serbian state. Turning to political plans for such a state, Judah cites the I840s programme drafted by the future foreign minister, Ilija Garašanin to include Bosnia as well as Kosovo. The ethnic concept of heroic mountain rebels as 'Dinaric men' ready to fight for its creation is traced to the early twentieth-century geographer, Jovan Cvijić. Taken together, the four combine the martyrdom of the Heavenly Kingdom chosen by Prince Lazar in the face of the Ottoman conquest in I 389 with the heroism of Dinaric men, ready to vindicate rebellion against any odds and recreate a Serbia within its original or linguistic borders after centuries of Ottoman victimisation.

The folk epics of Karadžić and the poetry of Njegoš are the strongest corners of Judah's framework for Serbian historical memory. Their prominence in school textbooks from the later nineteenth century through the communist period is well known. ${ }^{5}$ The linkage from Garašanin to Cvijić as a guide to modern Serbian politics from I860 to the First World War is less clear than the use to which it would be put in the I990s. There would be no place in textbooks for the Greater Serbia

5 See Charles Jelavich, South Slav Nationalisms, Textbooks and Yugoslav Union Before 1914 (Columbus, OH: Ohio State University Press, I990) and Andrew B. Wachtel, 'How to Use a Classic: Petar Petrović Njegoš in the Twentieth Century', in John R. Lampe and Mark Mazower, eds., National Ideologies and National Identities, The Case of Twentieth Century Southeastern Europe (Budapest: Central European University Press, 2004), I3I-53. 
outlined in Garašanin's famous Naćertanije. It was not made public until I906, as Judah acknowledges (p. 59). Nor does he suggest that Serbia was contemplating war with Austro-Hungary after its annexation of Bosnia-Herzegovina in 1908, or was any more than indirectly involved with the young Bosnian Serbs who assassinated Archduke Franz Ferdinand in I9I4. Moreover, any inference of contemporary political influence from Cvijićs ethnological concept of rebellious mountain men committed to reclaiming Kosovo is difficult to connect with his own pre-I9I4 and wartime commitment to a federal Yugoslavia, in opposition to the centralist Serbian majority. In October I9I8, he argued that, 'Yugoslavia must be a federation, with full equality of certain regions - the United States of Yugoslavia', including Bosnia if not Kosovo in that list of regions. ${ }^{6}$

Judah's limited account of Serbian state policy before I9I4 suffers from only a short list of exaggerations, omissions or errors. He inflates the size and fanfare of the r 889 commemoration of the 500-year anniversary of the Kosovo battle, muted in fact for fear of Austrian reaction, rather than encouraged by Vienna. There is no mention of the constitutional monarchy, press freedom and multi-party politics that marked the first years of King Petar Karadjordjevic's reign from I903. Serbia's I9I2 treaty for the division of Macedonia was signed with Bulgaria, not Greece. The Carnegie Report on the Balkan Wars of I9I2-I3 could not report on Serbian depredations in Kosovo because the Serbian authorities did not allow Commission members to enter. But in his chapter on ethnic cleansing, entitled 'Burning Villages', which cites Njegošs The Mountain Wreath as having encouraged such acts, Judah fairly notes that the Report found all sides guilty of depredations (p. 82).

Less than ten pages on inter-war Yugoslavia are simply too skimpy to make a connection from the pre-I9I4 period to the Second World War and the Tito regime, also covered quickly in barely fifty pages. There is no distinction between the two inter-war decades, which the new state is said to have 'tottered through as a poor, unstable and sullen country' (p. I09). The divisions within Serbia and with Croatian and Bosnian Serbs in the parliamentary elections of the I920s are ignored in favour of the 1928 assassination of the Croatian leader Stjepan Radic in that parliament and King Aleksandar's royal dictatorship of 1929. The longer treatment of the Second World War puts the German collaborationist regime of Milan Nedić in power at once without mentioning the Nazi reign of terror in Serbia from April to August I94I that preceded it. The one genuine Serbian fascist, Dimitrije Ljotić and the collaborationist Chetnik leader Kosta Pečanac are not, however, lumped tendentiously together with Draža Mihailović, the old regular army resistance leader for the London government. Judah also confines evidence of Mihailovićs often alleged intention to eradicate Muslims and create an ethnically pure Greater Serbia as a wartime goal to a single atrocity, also adding Mihailović's denial in his post-war Communist show trial (pp. I2O-I).

\footnotetext{
${ }^{6}$ Ljubinka Trgovčević, 'South Slav Intellectuals and the Creation of Yugoslavia', in Dejan Djokić, ed., Yugoslavism, Histories of a Failed Idea, 1918-1992 (London: Hurst, 2003), 235.
} 
The same dispassionate approach takes us through the rise of Josip Broz Tito's partisans and the long post-war communist regime. After acknowledging wartime abuses by the Croatian Ustaša and Kosovar Albanians, Judah's brief treatment of the period $1945^{-89}$ does concentrate on the Serbian sources of dysfunction within the regime. This is fair enough for the repressive pre-1966 role of Aleksandar Rankovic and his security forces, especially in Kosovo. But it is too simple a scenario for the subsequent struggles with a convoluted, increasingly confederal framework that could function only as long as Tito was alive to oversee it.

Drapac also promises 'a dispassionate interrogation' (p. 2) of an apparently broader topic, the creation of a Yugoslav state and the idea of a Yugoslav nation. Drapac proposes setting the construction of both Yugoslavias in the newly popular transnational approach, going beyond traditional diplomatic history to provide a larger comparative perspective offered by academic engagement and popular perception. Drapac adds a second scholarly framework to her enterprise, one that would have helped to connect the two halves of Judah's book more clearly, the role of collective historical memory.7 She makes good use of it for the collective memories of Serbs and Croats. But we quickly learn that the volume's principal piece of transnational interaction is instead the leading British role in making both Yugoslavias 'what outsiders willed it to be'. Domestically ascendant wartime elites of I9I 8 and I945 (i.e. the Serbian and partisan armies) could then proceed unchecked against democratic prospects and individual rights (pp. 8-9). Her conclusion dismisses the Yugoslav idea as divorced from the reality of the states created in I9I 8 and I945. They lasted as long as they did only because outsiders considered them 'necessary' (pp. 337-8).

The bulk of the book is more dispassionate. Almost a hundred pages apiece are devoted to two long periods, I850-I920 and I920-I945. The principal villains of her piece are still the British travellers, journalists and scholars, less clearly joined by diplomats. The author cites Maria Todorova's correlation between the views of British visitors to the Ottoman Empire and British foreign policy as a prestigious precedent for her approach. ${ }^{8}$ Drapac draws directly on the papers of various unofficial visitors, increasingly focusing on the journalist and historian R. W. Seton-Watson. Official British documents, including the reports from the Belgrade embassy noted in the bibliography, are not often cited. Her citations from secondary sources are wide ranging but inclined toward the argument first and most persuasively advanced by Ivo Banac that the Croatian and Serbian national ideas were already incompatible by the time that the I92 I constitution ratified Serbian domination of an 'untenable centralist solution of Yugoslavia's national question'. ${ }^{9}$ For Drapac, Serbian domination

${ }^{7}$ For a detailed review of the extensive literature, see Peter Fritzsche, 'The Case of Modern Memory', Journal of Modern History 73, I (March, 200I), 87-II7.

8 Maria Todorova, Imagining the Balkans (London: Oxford University Press, 1997).

9 Ivo Banac, The National Question in Yugoslavia: Origins, History, Politics (Ithaca, NY: Cornell University Press, I983), 404. For a recent review of the variety of pre-I989 explanations offered for the collapse of Yugoslavia after I989, see Jasna Dragović-Soso, 'Why Did Yugoslavia Disintegrate: An Overview of Contending Explanations', in Lenard J. Cohen and Jasna Dragović-Soso, eds., State Collapse in 
derived from an accumulation of British support that made its wartime suffering on the Allied side into a justification for the centralist regime in Belgrade.

She opens her indictment with a series of English magazine articles from the I870s that express a preference for the Balkan Orthodox Christians over the Habsburg Catholics bound to the papacy as well as their own clerical hierarchy. Arthur Evans, the pioneer archaeologist of Bosnia, is identified as a leader in such British sympathy away from the Bulgarians, originally favoured in the famous William Gladstone pamphlet on 'the Bulgarian Horrors of 1876 '. Drapac repeatedly cites Evans's I 880 article on 'The Austrian Counter-Revolution in the Balkans' to identify his Protestant preference for independent, Orthodox Serbia and record his suspicion of 'the Latinized, bigoted priesthood' that denied 'the inferior, at first sight repellent Croats' their freedom from 'the supranational Papacy'(pp. 50-5). As we shall see, she pursues this British disposition to denigrate the Croats and favour the Serbs, persuasively argued for the late nineteenth century, into the inter-war Yugoslav kingdom.

For the rest of the pre-I9I4 period, Drapac concentrates on a steady growth in British support for Serbia. She dismisses the British break in diplomatic relations with Serbia from 1903 to I906, following the assassination of King Aleksandar Obrenovic, as 'short-term damage' (p. 6I). There is no mention of the French loans and Russian diplomatic support that far outweighed British interest throughout the last pre-war decade. Seton-Watson is introduced only as a friend of Evans. We see no discussion of his 'dislike of Serbian politics', precisely because of the royal assassination, which he brought to Belgrade on his first visit in 1908 between more frequent and appreciative visits to Zagreb. ${ }^{10}$

The First World War provides a more convincing case for decisive British favouritism. The widespread official propaganda, the relief efforts from civil society and the public admiration for 'Gallant Serbia' deserve Drapac's detailed presentation. The single source discounting the Serbian army's contribution to the French-led breakthrough on the Salonika front in I9I8 is less convincing. More seriously for her argument, the December I9I 8 proclamation and the subsequent creation of the Kingdom of Serbs, Croats and Slovenes are presented with no sources as resting on 'the foundation of the enormously successful lobbying and fund-raising on behalf of the Serbs by the Allies' (p. 65). Here the general risk for transnational history of working on the assumption of a parallel diplomatic record should be noted. In the event, the momentum of wartime propaganda and relief programmes did not prompt Britain or France even to recognise the new kingdom until mid-I9I9 or to offer the sort of post-war loans which the French government had provided Serbia before the war. Nor do we find any evidence from the diplomatic record of how Seton-Watson's

Southeastern Europe: New Perspectives on Yugoslavia's Disintegration (West Lafayette, IN: Purdue University Press, 2009), I-39.

${ }^{10}$ Hugh Seton-Watson and Christopher Seton-Watson, The Making of a New Europe, R. W. SetonWatson and the Last Years of Austria-Hungary (Seattle, WA: University of Washington Press, I98I), 6I. For evidence of a less forgiving British view of Serbia after the I903 assassination, see Slobodan G. Markovich, British Perceptions of Serbia and the Balkans, 1903-1906 (Paris: Dialogue Association, 2000). 
surely strong support for such a state found its way into the decisions made by the Foreign Office or the British leadership at the Paris Peace Conference, or how the Serbian side relied on them. Still standing without evidence to the contrary is Ivo Lederer's original emphasis on British support for the new state and its formidable Serbian army as a barrier against Italian ambitions, fed from I9Is by Britain's now embarrassing concession of Dalmatia in the London Treaty, and a guardian against Austrian or Hungarian revanchism. ${ }^{11}$

For the rest of the inter-war period, Drapac can, however, track Seton-Watson's continuing support of the kingdom as a worthy enterprise, finally paralleling his support to Britain's diplomatic representation in the I930s. Despite his advocacy for an ethnically balanced state through his publication of The New Europe earlier in the I920s, Seton-Watson did go on in I929 to welcome King Aleksandar's repressive royal dictatorship as resolving the 'cruel dilemma of party chaos', reassured at the same time by 'Serbia's absolutely and fundamentally democratic nature' (pp. I23-5). In contrast, she can point to descriptions of Croats in a series of British and French journals as 'irascible, problematic ... difficult and restless'. The British minister to Belgrade, Nevile Henderson, joined Seton-Watson in initial approval of the dictatorship and then maintained it throughout his tour from I929 to I935. Drapac frames Henderson's support pejoratively between his youthful aid to Protestant Unionists in Northern Ireland and his subsequent accommodations to Hitler's Germany Ambassador in Berlin. A more fitting framework might be the general disposition of inter-war British diplomacy to favour the monarchies of south-eastern Europe. More convincingly, Drapac can point to Serbian mistreatment of Kosovar Albanians ignored by SetonWatson but detailed by his English contemporary, Edith Durham. Fair attention is also called to the divisive effect in Croatia of the Serbian monopoly on memorials to commemorate the dead in the First World War. ${ }^{12}$

Fair attention to the full range of English-language scholarship does not continue into the Second World War and beyond. First anti-Serb and then anti-communist, these brief chapters string together a series of pejorative points whose specifics call into question the author's claim to a dispassionate approach. The Serb Chetnik resistance movement of Mihailović, its scattered forces disconnected from his command and control, is connected not only to coordinated killing of Croats and Muslims but also to the collaborationist Nedic regime in Serbia. Leaving the reader with the impression that Nedić was put in place at the same time as the Croatian fascist regime of Ante Pavelić, Drapac goes on to equate their authority and abuses. She rejects the generally accepted judgment that the Serbian administration was the more subordinate, directly installed by the Nazi military occupation five months after arriving after relying on terror tactics and several thousand executions to subdue the

11 Ivo Lederer, Yugoslavia at the Paris Peace Conference, A Study in Frontiermaking (New Haven, CT: Yale University Press, I963).

12 See Melissa Bokovoj, 'Scattered Graves, Ordered Cemeteries, Commemorating Serbia's Wars of National Liberation', in Maria Bucur and Nancy M. Wingfield, eds., Staging the Past, The Politics of Commemoration in Habsburg East Central Europe from 1848 to the Present (West Lafayette, IN: Purdue University Press, 200I), 236-54. 
population (p. I55). Instead, Serbian collaborationists are given the same lead in the killing of Jews in Serbia as the Ustaše did in Croatia. The Ustaše regime, and the latter's designation as 'fascist' is questioned. Drapac is on stronger ground when she returns to contemporary Western perceptions, criticising the oversimplified condemnation of the Croatian Catholic Church and the sympathetic stereotypes that helped to sustain British support for the Serb Chetniks and Mihailović into I943.

A brief concluding chapter on Tito's post-I945 Yugoslavia begins promisingly with the acknowledgment that external forces supported this second Yugoslavia more as reaction than initiation. Recent scholarship on the communist-controlled election of I945 supports her view that the British left jumped to support the heroic partisans' new socialist project. ${ }^{13}$ But the same study finds disillusion already setting in by 1948 . After the Tito-Stalin split, Drapac transposes British and especially American financial support for 'keeping Tito afloat', which ended by I96I, into unrepayable 'endless loans' that sustained the regime for decades. World Bank loans were indeed sizeable, but all were repaid on schedule. Domestic support for Tito's Yugoslavia is dismissed in an off-hand comparison with a German public cowed by Nazi propaganda and police (p. 246). Tito's support for the Soviet intervention in Hungary in 1956 is mistakenly transposed to Czechoslovakia in I968 (p. 220). Readers will need to look elsewhere for how in fact the Anglo-American appreciation of a more open and less repressive Yugoslavia by the I960s, coming from more than the British left and the scholarly cadre of veterans from British wartime assistance to the partisans, turned out to be misplaced by the I980s. ${ }^{14}$

Djokic has written a less ambitious book that does not reach even as far as its subtitle, 'A History of Inter-war Yugoslavia'. Its main title is more apt, indicating that inter-war political relations between Serbian and Croatian political leaders offered them a chance for compromise, however elusive. His consciously instrumental approach' (p. Io) to these relations as a process in their own right takes us away from the 'intentionalist approaches' considered so far, Drapac's to what might be called Serbian national centralism and Judah's to the Serbian national mythology as mobilised by the Milošević regime.

A brief initial chapter highlights the ambiguities and divisions in the Serbian and emigré Dalmatian Croat positions during the First World War concerning a future Yugoslav state. Djokic then proceeds from the I92 I constitution, described in Banac's classic intentionalist argument as a dead end for two irreconcilable national ideologies. ${ }^{15}$ The next three chapters emphasise Serbian and Croatian Serb political divisions during the I920s, the range of political reactions to the royal dictatorship

13 Jim Evans, 'Britain and the Yugoslav General Election of I945', in Andrew Hammond, ed., The Balkans and the West, Constructing the European Other, 1945-2003 (Aldershot: Ashgate, 2003), I-I5.

14 Political doubts may be seen in Steven L. Burg, Conflict and Cohesion in Socialist Yugoslavia, Political Decision Making Since 1966 (Princeton, NJ: Princeton University Press, I983) and an accurate forecast of economic failure in Harold Lydall, Yugoslav Socialism: Theory and Practice (Oxford: Clarendon Press, I984).

15 Djokić frames his volume as filling in the gap between Banac's The National Question in Yugoslavia, which calls it unanswerable by I92 I and for the rest of the inter-war period. 
and territorial reordering of I929, and the struggle to mount a joint Serbian-Croatian opposition to it before and especially after Aleksandar's assassination. Two concluding chapters then examine the I939 agreement that created a large, internally autonomous Croatian banovina and its fatal consequences for the joint opposition.

Expanded from a doctoral dissertation on the 1939 Sporazum, the volume pays more attention to the I930s, over two thirds of its pages. Its concentration on the discourse - not always a direct dialogue - between leading Serb and Croat figures does not include the institutional, socio-economic or cultural relations that would be needed to justify the ambitious subtitle on which the publisher (presumably) insisted. Nor does it pay close attention to King Aleksandar's growing influence at the centre of the kingdom's institutional framework even before the royal dictatorship of I929. ${ }^{16}$ But its examination of what is often assumed to be a frozen Serb-Croat conflict does reveal enough effort and change over time to challenge the thesis of irreconcilability, while still admitting that successful compromise remained elusive.

The first two chapters serve to support his challenge. Wartime exchanges between factions in the Serbian political leadership reveal uncertainty about what form a future Yugoslav state should take. None of them used the designation Greater Serbia. Picked up instead by British and French representatives as Drapac might expect, this designation's only diplomatic manifestation was a brief I9I5 offer of some unspecified 'Habsburg territory' in return for ceding Vardar Macedonia to Bulgaria and thus luring Sofia away from the Central Powers, which it promptly joined anyway (pp. I6-I7). As for the Yugoslav Committee in London, neither of its two Dalmatian Croat leaders favoured a federal Yugoslavia. Frano Supilo wanted no part of any future relationship with the existing Serbian government. Ante Trumbic attended the famous joint Corfu conference of I9I7 and rejected any future federation in favour of his woolly notion of a 'unitary but decentralized state' (p. 20)

Djokic then reviews a variety of proposals for the I92 I constitution during the two full years of debate that preceded it. Three separate Croat-Slovene proposals for federation accepted the Serbian monarchy, leaving only the Croatian Republican Peasant Party (HRSS) led by Radić to demand a confederal republic. On the Serbian side, the small Socialist and Agrarian Parties also plugged for a republic. The more influential Stojan Protic put forward a plan for nine historically based provinces with more local rights than the thirty-three French-style districts of the Vidovdan Constitution would provide. And in the next years of multi-party politics, the Democratic Party faction led by Ljuba Davidovic pressed, albeit unsuccessfully, for 'cultural unification and decentralized administration' as a 'third way' between the Radić-led HRSS boycott of the parliament and the Nikola Pašić- and Radical-led coalition governments. But after Davidovic had his brief 'hundred-day government' in I924, the three-cornered conflict between Pašić, Radić and the Croatian Serb leader Svetozar Pribićević could resume.

16 On rising royal influence, see Mark Biondich, 'The Historical Legacy: The Evolution of Interwar Yugoslav Politics, I9I8-I94I', in Cohen and Dragović-Soso, State Collapse in South-Eastern Europe, 43-74, here $58-9$. 
As is well known, the subsequent set of governments took turns combining two of these three figures until Pašić died in I926 and Radić was assassinated in I928. As for British perceptions, it is worth noting that British minister H. W. Kennard in Belgrade expressed none of the preference that Drapac would assume for 'Serbism' over 'Croatism'. Her case for official British support of the royal dictatorship does, however, benefit from Djokić's account. We learn that Kennard called its imposition 'essential ... quite apart from the questionable manner in which this absolute autocracy was introduced', while Seton-Watson called it relatively 'benign' in comparison with Ataturk's Turkey or Zog's Albania (pp. 72, 278). Djokić's own case for Serb-Croat exchanges points to the initial approval of the parliament's dissolution by Radić's successor, Vlatko Maček. But it does not gain much from citing the subsequent presence in subordinate positions of ten Croats in the repressive, otherwise Serb-dominated regime of I929-3I. Here the absent institutional details of the regime's expanded authority and abuses would have shown the obstacles to any future compromise between Serb and Croat party leaders in an initially non-party regime.

When those anti-party obstacles did retreat, especially after Aleksandar's assassination, Djokić can track the bargaining between Maček and other party leaders that would lead to the joint Serb-Croat opposition movement of $1935-8$. It began unsuccessfully in 1932 with the 'Zagreb points' of opposition that put Maček in prison until I934. Similar points followed quickly from Ljubljana and Sarajevo. The attempt of Serbia's political opposition to follow suit foundered instructively on a failure to agree among its own components.

The same divisions would trouble the Serbian side in its efforts to join forces with the moderates that emerged in Maček's revived Croatian Peasant Party (HSS). (Its cooperative network had helped the party to expand despite the Belgrade regime's formal restrictions.) Maček's own insistence on rejecting the I92 I constitution as well as the royally imposed one of I93 I helped to assure that no compromise could be reached either with Prince Paul's new regency or the I935-8 government. This government's leader, Milan Stojadinović, expressed a desire to add the 'fourth leg' of the Croatian Peasants to the coalition of Serbian Radicals, Bosnian Muslims and Slovene clericals to his newly authorised political party, the Yugoslav Radical Union (JRZ). Djokić notes that Stojadinović's condescension combined with Maček's insistence on going back to I9I8 made their one meeting in I937 a failure (pp. II7I8). But by I938, enough Serb-Croat agreement had been reached to bring Maček to Belgrade for a welcoming crowd of some 50,000 and then to field a joint list against Stojadinović's JRZ in the autumn elections. Their list won I.3 million votes, not enough to defeat the JRZ but close enough to its I.6 million votes to force him to resign. Of the opposition total, 600,000, or almost half, were Serbs, albeit mainly from outside of Serbia. It is also worth noting, as Djokic does, that the only other list was indeed for Ljotićs's pro-fascist ZBOR nationalist movement, but it won a grand total of 30,000 votes.

The election results also left Maček in a strong position to bargain with the regency's new Serbian prime minister, Dragiša Cvetković. After a false start in April 
I939, they reached an August agreement, or Sporazum, on a new Croatian banovina that would add the Dalmatian Primorje plus seven districts from Bosnia-Herzegovina and Dubrovnik. Djokić concludes his final chapter by calling the agreement, despite its flaws, 'a positive step toward finding a Serb-Croat compromise' (p. 268). His detailed discussion of its immediate consequence is not, however, reassuring about the prospect for further positive steps. The rising Serbian demands for an enlarged banovina of their own, one that would include the rest of Bosnia and Herzegovina, posed the most obvious problem. Djokić concedes, as the Hoare volume discussed below goes on to explore in detail, that the Serbian demand directly conflicted with aspirations of the Bosnian Muslims. Some of them in Sarajevo, satisfied prior to the I938 election and the Sporazum by the partnership of their Yugoslav Muslim Organization (JMO) in Stojadinović's ruling JRZ, now began to speak out for their own autonomous region.

Meanwhile, as revealed in Croatian archival documents, local Serb officials, police and teachers were being dismissed under the autonomous administrative framework afforded the new Croatian banovina despite its leadership's disapproval (p. 244). This did not bode well for Bosnia, particularly in the more likely event of its inclusion in an enlarged Serbian entity. But Djokićs volume does make the case for enough Serb-Croat agreement, with Maček continuing in the government until the Nazi attack in I94I, to dispute the argument of Drapac and others that the inter-war state was disintegrating of its own accord. He also calls attention to the disunity in the post-Sporazum movement ironically titled 'Serbs Rally Together' and to differences of opinion in the Serbian Cultural Club too easily identified with its Bosnian Serb, exclusionary nationalist leader, Stevan Moljević. Djokić's contribution throughout is to show how at least some of the divided Serbian, Croatian Serb and Bosnian Serb political spectrum repeatedly pursued a compromise agreement with a largely united Croatian side. The Serbs' division also denied any of their individual parties the authority to control the institutional framework with which the I92I constitution and the royal dictatorship burdened all non-Serbs.

Hoare turns from the focus of Drapac and Djokic on Serb-Croat relations directly to the problems posed by the three-cornered interaction of Bosnian Muslims (or Bosniaks), Serbs and Croats. Their overlapping history is obviously relevant to the unexpected violence of Yugoslavia's wars of dissolution. Over I00,000 people perished in Bosnia, the great majority of those killed overall. This Bosnian warfare is granted the largest part of Judah's treatment. Hoare's own title reaches from the medieval period to the warfare of the I990s and beyond but concentrates on neither. Well over half of his new history of Bosnia deals with the period from the founding of the first Yugoslavia through the Second World War and into the second Yugoslavia. His concentration, like Djokić's, comes out of a doctoral dissertation, here on the partisan experience in Bosnia during the Second World War. Its influence on this volume may be seen in chapters added for the both inter-war and I94I-5 years. One follows the pre-I9I4 socialist movement into the inter-war Communist Party (KPJ) and the other provides a separate account of the partisan-led 'rebirth of the Bosnian state' in the Second World War. And indeed the legitimacy of those aspirations for a 
multi-ethnic state, sounding very much like a smaller version of the Yugoslav idea, is the moral narrative of Hoare's account of Bosnia's history across these earlier decades of the twentieth century.

Now the most detailed account available in English, the volume ranges across some of the primary sources and most of the sizeable domestic scholarship available in Belgrade and Zagreb as well as Sarajevo. Hoare's acknowledgment of Croatia as 'his spiritual homeland' does not keep him from levelling some hard judgments on the I94I-5 Independent State of Croatia that Drapac softens. But anywhere in the volume that Serbian interests from Belgrade are concerned, he draws a more direct line than Judah does from them to the anti-Bosniak abuses by Bosnian Serbs and the Milošević regime in the early I990s.

Hoare begins this less balanced feature of his volume by making the conspiratorial clique in pre-I9I4 Serbian military intelligence, known initial as the Black Hand, the direct instigators of the plot to assassinate Franz Ferdinand in Sarajevo (p. 89). ${ }^{17}$ He goes on to assert the still more questionable and undocumented connection of 'the remnants of the Black Hand' to the core of the Serbian Cultural Club and the military officers who overthrew Prince Paul's regency in April I94I (p. I50). The coup itself is doubtfully stripped of any anti-Axis motivation in favour of Greater Serbian ambitions. The German conquest is simply attributed to 'the political bankruptcy of the Yugoslav state'. Hoare, like Drapac, places the initially Serbian resistance movement led by the royal army's Mihailovic in exaggerated control of disconnected bands of Bosnian Serb Chetniks and more influenced by exclusionary nationalist, Bosnian Serb political advisors than the limited record suggests. Bosnian Serb Chetniks are said with even less evidence to 'widely view' Nedić, head of the collaborationist regime in Serbia, as 'their natural leader' (p. 259). Unlike Judah, Hoare dismisses any question about Mihailović's direct responsibility for a Montenegrin Chetnik band's murder of 8,000 Bosnian men, women and children in adjoining villages in 1942. Hoare uses this clear-cut atrocity to characterise Mihailović-led activities across Bosnia and Herzegovina as a coordinated Serb campaign of genocide against Bosnian Muslims and Croats. Stevan Pavlowitch's recent history of the wider war joins with other recent studies based on a wider set of primary sources to contradict this simplified narrative. ${ }^{18}$ None of them, it should be added, exempts the disconnected Chetnik bands, particularly those from Montenegro, from genocidal war crimes that mix revenge with ethnic cleansing at a minimum.

Neither this simplified moral narrative, often supported by communist-era historiography from Belgrade, nor Hoare's curious transfer of responsibility for Bosnia's inclusion in the Independent State of Croatia from the Ustaše to the Nazi

17 The initiative and most of the organisation of the plot is attributed to Gavrilo Princip and the other young Bosnian Serbs themselves in what remains the most detailed inquiry into assassination, Vladimir Dedijer, The Road to Sarajevo (New York: Simon and Schuster, I966).

18 Stevan K. Pavlowitch, Hitler's New Disorder, The Second World War in Yugoslavia (New York: New York University Press, 2008), passim; Simon Trew, Britain Mihailović and the Chetniks, 1941-42 (London: Macmillan, I998), I34; Jozo Tomasevich, War and Revolution in Yugoslavia, 1941-1945, Occupation and Collaboration (Stanford, CA: Stanford University Press, 200I), 82-4. 
leadership should discourage the reader from following his account of Bosnia's internal political history, particularly across the inter-war period. The several-sided issues confronting Bosnian Muslim, Serb and Croat relations receive close and informed attention. And only informed readers will easily follow the daunting number of political persons and parties.

Even before I9I8, Hoare notes condemnations from Muslim and Croat clergy for Serb persecution after the I9I4 assassination and also support from two of the three Bosnian Serbs on the wartime Yugoslav Committee for preserving Bosnia's territorial integrity in a post-war federal framework (pp. 9I-7). He calls our attention to the class difference that led the bulk of the Bosnian Serb peasantry, long beholden to sharecropping obligations by Bosniak landlords, to back the Serbian Radical Party and its promise of sweeping land reform in the 1920 elections to the Constituent Assembly. The base of the Bosnian Serb Radicals was to stay there into the I930s, under the leadership of Milan Srškić. The third Bosnian Serb in the Yugoslav Committee, he had opposed a separate Bosnian entity then and promoted demarcation among the new banovine in 1929 that eliminated any such entity.

His Bosnian opponents, along with some urban Serbs and a branch of the HSS, were the Bosnian Muslims. They were mobilised in and around the new JMO. Their leader Mehmet Spaho had already served as Secretary of the Sarajevo Chamber of Commerce and supported the creation of the inter-war state against the opposition of the older Bosniak elite of Muslim clergy and landlords. With rural landowners much weakened by redistributions of the I92 I land reform, Spaho was free to consolidate the JMO on the urban base from which he came. Its victory in Sarajevo's first municipal elections in 1928 marked a highpoint before the royal dictatorship cut short first its local authority and then Bosnia's territorial integrity.

Hoare carries us through the neglected history of the JMO into the I930s. We see Spaho's skill in using the Bosniaks' urban economic base. It did not suffer from the Muslim clergy's loss of Bosnian autonomy in I930. Following the king's assassination and the brief, badly failed tenure of Srškic as prime minister, the new regime of Stojadinović sought out both Spaho and the leader of the Slovene clerical party as partners in his new JRZ. This political leverage allowed Spaho not only to reacquire Muslim religious autonomy but also to consolidate the JMO's control of the railway administration and the major timber-exporting enterprise. Its orbit was extended even to the new Nazi-supported steel mill at Zenica (pp. I2O-3).

None of this was sufficient to re-establish Bosnian territorial integrity let alone promote autonomy before Spaho died in June 1939. Then in August came the Sporazum and its incorporation of those seven districts into the enlarged Croatian Banovina. Hoare does not spare Bosnian Croats and Bosnian Muslims any more than the Bosnian Serbs from their turn to exclusionary programmes. The incorporated Croats soon found themselves neglected by the new administration in Zagreb, while those in the remainder felt threatened by Muslim or Serb demands. Ustaše recruiting accelerated accordingly. Spaho's JMO successor, concluding that Belgrade had abandoned Sarajevo, pressed only for a Bosnian banovina within a new federal framework. But a new group calling themselves Young Muslims called for a separate 
territory excluding Serbs and Croats. The aims of the Bosnian Serb faction in the Serbian Cultural Club, if not as predominant as Hoare suggests, saw no place for a Bosnia separate from Serbia. These three exclusionary agendas nonetheless set the stage for the violence of the Second World War, a patchwork made more violent by the agendas of the Axis forces and the communist partisans. More attentive to complexity on the Bosniak side, Hoare traces the creation and 1943-44 conduct of the Bosnian Muslim SS Division to a domestic initiative to win Bosnian Muslim autonomy within the Independent State of Croatia and to a desire for revenge against the Serbs for Chetnik atrocities in I94I-2. He leaves no room for the anti-Jewish initiative of the Grand Mufti of Jerusalem as postulated in some recent German scholarship but confined in fact to his two-day visit to Sarajevo.

Only Tito's Bosnian partisans emerge from the war with the author's approval. Bosnia's partisan leadership, despite its larger Serb numbers throughout, persuaded Tito's high command to create a single liberation movement by I943 for what was to be a single republic. When the new republic's constituent assembly convened in 1945 , its delegates allowed no mention of Serbs, Croats or Bosnian Muslims, let alone their separate interests. Hoare's brief chapter on the period 1945-92 quickly disabuses us of the high hopes for a democratic and multi-ethnic republic that the author shared with the wartime communist assemblies. With Young Muslims and Croat Ustaše prosecuted, Bosnian Serbs held the upper hand in the republic's Communist party until the aforementioned fall of Rankovic in I966. There followed a couple of more promising decades for Yugoslavia and the Bosnian Muslims than the Judah or Drapac volumes allow, again building on urban integration and economic advances. In I9925 , the close and sometimes criminal connection between Bosnian Serbs and Serbia presumed for the Second World War became all too real. But throughout, if only for Bosnia-Herzegovina, Hoare is sustained by a belief in multi-ethnic accommodation that he shares, while not sharing much else, with Djokic and the vanished Yugoslav idea.

The multi-ethnic populations mixed within countries identifying themselves as nation-states continue to pose challenges to contemporary Europe. The history of how the two states called Yugoslavia fared and failed thus deserves attention. So, however, do the Serbs, a people who came from or felt ethnically bound to a really existing nation-state that preceded the first Yugoslavia. How the Serbs and the two multi-ethnic states proceeded from there brought all four of these volumes to the Serbian question. Their more convincing arguments concern what turned out to be transnational relations between the Serbs and the other ethnic groups inside those vanished common borders. 